\title{
ЛИТЕРАТУРОВЕДЕНИЕ
}

\author{
УДК 398
}

DOI: $10.21779 / 2542-0313-2019-34-2-27-32$

\section{Р.М. Магомедова}

\section{Сатира и юмор в аварской народной поэзии}

Дагестанский государственный университет; Россия, 367001, 2. Махачкала, ул. М. Гаджиева, 43a; diyarbilova@mail.ru

В статье исследуются особенности использования сатиры и юмора в аварском народном песенном творчестве. Прослеживаются способы создания сатирических и юмористических произведений в различных жанрах аварского фольклора, обращается внимание на специфические особенности использования форм проклятий в аварской любовной лирике и на соответствующие национально-культурные компоненты. Отмечается, что рассматриваемые вопросы представляют интерес не только для фольклора, но и для этнолингвистики и лингвокультурологии, поскольку именно фольклорные тексты отличаются национальной самобытностью и особой национально-культурной символикой. Отмечены собственно лингвистические особенности, как, например, экспрессивно-оценочное использование форм единственного числа существительных в значении множественности. В аварском народном песенном творчестве отражаются особенности национального менталитета, разного рода гендерные признаки, связанные с языковыми мускулинными и фемининными символами, ставшими культурными знаками аварского языка и получившими в историческом плане своеобразную интерпретацию. В статье также обращается внимание на перспективы изучения фольклорных песенных текстов.

Ключевые слова: аварский фольклор, песенное творчество, сатира и юмор, национально-культурные компоненты, языковые средства.

Особенности использования сатиры и юмора в аварской народной поэзии недостаточно изучены, хотя они имеют лингвистическую и лингвокультурологическую значимость. В перспективе могут быть исследованы языковые средства иронии и сатиры и особенности национально-культурного характера, поскольку в народной поэзии аварцев отразились опыт, мудрость, менталитет, психология и культура.

Возрастающий интерес к устному народному творчеству обусловлен стремлением того или иного народа выявить свое место в историческом прошлом, осмыслить свой вклад в сокровищницу мировой культуры.

Аварский народ в течение многих веков создавал богатую духовную культуру, и в ней большое место занимает народная поэзия, в которую входят календарнообрядовые, свадебные, колыбельные песни, песни-причитания; народные баллады и лирические песни.

В данной статье мы рассматриваем в основном тексты внеобрядовых народных поэтических произведений, в которых ярче всего отражаются сатира и юмор. 
Внеобрядовую лирику аварцев составляют пейзажные, философские, героические, любовные и детские песни. Жанр лирической песни является ведущим в аварском фольклоре, так как лирические песни отражают жизнь народа.

В трудах Петра Карловича Услара [11], Адольфа Дирра [3], в первых публикациях на национальных языках Айдемира Чиркеевского [13], Магомеда-Эфенди Османова [8], Абусуфьяна Акаева [7], посвященных истории собирания, публикации и изучению дагестанского песенного фольклора в дореволюционное время обращается внимание на характерные для горского фольклора народов Северного Кавказа метафорические образы, сравнения, эпитеты.

Из народной аварской лирики можно выделить группу сатирических и шуточных песен. Они раскрывают недостатки общественной и частной жизни, направлены против конкретных уродливых явлений в жизни народа.

В аварской народной поэзии сатирическая песня затрагивает, как правило, социальные темы. И при этом главную роль в идейно-художественной структуре этого типа песен играет ирония, являющаяся одним из важнейших способов создания сатирического образа. Большое место в таких песнях занимает тема труда.

В народных сатирических песнях безжалостно высмеиваются лень, трусость, безответственность и многие другие человеческие пороки. На характер сатирических песен наложили свой отпечаток непростые условия жизни аварцев, их культура, быт, национальный характер.
ЧІалаби мичІчІил дур,
Брёвна из крапивы,
ГІурдул чІарал дур.
Жерди из сорняка.
ХІанчІил гьан нахъльолев,
Мясо на зиму из птицы,
Квен ридидулав.
Еда из сыворотки.

Такие слова-насмешки присутствуют в фольклоре унцукульцев. В этой песне народ высмеивает ленивого, нетрудолюбивого человека, который не думает о завтрашнем дне: ни о доме, ни о хлебе насущном.

Аварская народная бытовая поэзия высмеивает не только лень, но и трусость, которую не прощают горцам-мужчинам:

\section{АхІуд бахІарзал индал, \\ ХІамил бокьов вахчулев, \\ Рузманалда чи индал \\ Чехьалда вегулев. \\ Мун гІадинав хІалихьат \\ Вихьизе вокьиларо. \\ ВатІаналде къо ккедал, \\ Рохьазде льутарулев...}

Когда на войну молодёжь собирается,

Прячешься в сарае для ослов.

Когда другие в мечеть идут,

Вверх животом лежишь и спишь. 
Такого труса и подлеца

Видеть больше не хочу.

Когда Родина в опасности,

В лесах прячешься ты...

Трусость никогда не оправдывалась даже горячо любящей матерью, поскольку горцы прививали сыновьям такие качества, как мужество, выносливость, готовность всегда заступиться за родную землю, за женщину и за свой народ. Мужчина должен быть не только храбрым и бесстрашным, но и внешне подтянутым и аккуратным, а отсутствие таких качеств становится предметом насмешек:

\section{ХІамил щватабазда шапка рельлъарав, Щибилан восилев мун ясалаца?}

Если шапка твоя на ослиные уши похожа, Как же девушкам выбирать тебя?

Здесь высмеивается неряшливость молодого человека, его неаккуратный внешний вид. Гендерно значимый символ шапки (=папахи) в оценочном плане приобретает в приведенном контексте особую значимость.

В другой народной песне с иронией говорится о состоятельном человеке, который имеет много овец (количество овец было показателем благосостояния и достатка горца), но из крайней скупости не носит достойной настоящего мужчины одежды:
МагІарда гІи гІемер,
Горы полны овец,
ГІин гьечІеб тІагъур.
А шапка без уха.
ГІияль куйдул чІахІав,
Бараны в отаре жирны,
ХІулараб тІимугъ.
А шуба облезлая.

Скупость и жадность, вызывают у людей негативное отношение и высмеиваются настолько остро, что ирония переходит в сарказм. Даже звучат проклятия в адрес скряги.

ГІебул маичІаль иุІан баги,

ЦІиІел лълъараль ханжу баги,

Хурул рагІал гІораль аги,

ГІачибачал пуяль аги.

Пусть соль лишь на кончике шила останется.

Пусть мука с козий рог останется.

Пусть река поля унесёт.

Пусть пурга коров и телят унесёт.

Интересные языковые средства используются и для ироничной и негативной оценки скупого человека.

ХинкІазда гІужал льолев,

ГІатІада гІучІал хъвалев,

ГІариуда кьаву чІварав,

ГІанкІуяль арал мугьал.
На хинкале метки ставящий, На муку замки вешающий, Деньги твои заржавели.

А зерно курицы унесли. 
В данном случае интересен прием экспрессивно-оценочного использования формы единственного числа гlaнкly «курица» в значении множественности.

В другой песне высмеиваются не только человеческая скупость, но и лицемерие, подхалимство, когда человек оценивает окружающих людей по материальному достатку.

Садакъадул къимат

КъваригІунго букІинчІо.

Къарумав чи мун вукІин

Цебего лъан букІана.

Дуцча садакъа кьолеб

Тайпа батІияб буго.

ГІадамал ратІагьари

Дурго битІараб гьечІо.
Как милостыня твоё уважение

Мне не было необходимо.

Что ты человек жадный,

Знал я давно.

Те, кому раздаешь милостыню,

Они люди другие,

Так различать людей

Несправедливо, пойми.

В аварской народной бытовой лирике встречаются песни, в которых осуждаются и высмеиваются клеветники и сплетники:
Гьаицулье ицІам балел маичІихъабайа
РаициІадал гІадамал гІужие гъола.
Ургъимес махІиарал хІалхъубалщиназ
ХъахІаб гІариудаги бугьтанал лъола.
Сплетники, что в мёд соль кладут,
Чистых людей на мушку берут.
Изнутри гнилые клеветники все
Белое [чистое] серебро очернить готовы.

Чёрными воронами называет народ таких людей. Языки у них сладкие, а сердца чёрные. «Стоит человеку отойти, они начинают обливать его грязью», - говорится о них в народной песне.

Даже в народной любовной лирике много сатиры и иронии в адрес нелюбимого мужа, жениха, влюбленных.

Для любовной лирики характерна форма диалога. Это обычно диалоги между матерью и дочерью, юношей и девушкой и т. д. Характерной чертой аварской народной любовной лирики является то, что объяснение в любви происходит в форме высмеивания любимого. Этим приёмом пользовались и аварские поэты (например, Анхил Марин в песне «Дуда чІор речІчІаяв» - «Чтоб стрела в тебя попала»). Иной раз объяснение в любви встречается в форме проклятий в адрес возлюбленного:

Дур багІараб чоча накабичІваяв,

Наку-кверищ чІвалеб дур кьибилалъе?

Кьолбода гьоркьоса вокьулев хваяв,

Багьана щииб батун, дун рехун тарай? 
Да чтоб красный конь колени тебе разбил, На колени что ль мне стать пред твоей роднёй?

Да чтоб самый близкий тебе из родни погиб, Какая причина, чтоб бросить меня?

Любовная тема в аварской народной лирике в основном хорошо разработана в работах С.М. Хайбуллаева. Фольклорный же материал, взятый из рукописного фонда НИИФЛИ ДГУ, используется в данной статье впервые. Следует обратить внимание на то, что в научных публикациях поднимаются проблемы взаимовлияния и взаимодействия фольклора и литературы. Так, особенности использования фольклорных мотивов в современной ашугской поэзии рутулов рассматриваются в статье К.Э. Джамалова [4, с. 36-41]. Фольклорные мотивы в творчестве Щазы Курклинской анализируются в статье Г.А. Мудуновой [6, с. 72-80]. На особенности межжанровых влияний в фольклорной прозе обращает внимание Л.Л. Ивашнева [5, с. 63-69]. В отдельных научных публикациях рассматривается проблема использования символики в поэзии и фольклоре $[9$, c. $45-50]$.

Обобщая материал исследования, следует отметить, что аварская народная поэзия богата и самобытна, в ней широко представлены сатира и юмор, придающие ее содержанию и форме оригинальность и неповторимость. Достаточно очевиден, как показывает иллюстративный материал, и национально-культурный компонент аварского народного песенного фольклора, который может представить интерес для этнолингвистики и лингвокультурологии.

\section{Литература}

1. Ахлаков А.А. Исторические песни народов Дагестана и Северного Кавказа. M., 1981.

2. Далгат У.Б. Фольклор и литература народов Дагестана - М.: Изд-во вост. литературы, 1962.

3. Дирр А.М. Очерки по этнографии Дагестана в Табасаранском округе. - СПб., 1903.

4. Джамалов К.Э. Фольклорные мотивы в современной ашугской поэзии рутулов // Вестник Дагестанского государственного университета. Сер. 2: Гуманитарные науки. - 2019. - Т. 34, вып. 1. - С. 36-41.

5. Ивашнева Л.Л. Нижневолжские легенды о Николае Чудотворце: к проблеме межжанровых влияний в фольклорной прозе // Вестник Дагестанского государственного университета. Сер. 2: Гуманитарные науки. - 2016. - Т. 31, вып. 1. - С. 63-69.

6. Мудунова Г.А. Фольклорные мотивы в творчестве Щазы Курклинской // Вестник Дагестанского государственного университета. Сер.: Филологические науки. 2014. - Вып. 3. - С. 72-80.

7. Литературное и научное наследие Абусуфьяна Акаева: сб. статей и материалов. - Махачкала, 1992.

8. Османов М.-Э. Поэзия народов Дагестана: в 2 т. - М., 1960. - Т. 1.

9. Тажудинова С.M. Символика в философской элегии Али-Гаджи из Инхо «Хъах1аб рас» («Седой волос») // Вестник Дагестанского государственного университета. Сер.: Филологические науки. - 2015. - Вып. 3. - С. 45-50.

10. Традиционный фольклор народов Дагестана / отв. ред. Г.Г. Гамзатов. - М.: Наука, 1991. 
11. Услар П.К. Кое-что о словесных произведениях горцев // Сборник сведений о кавказских горцах. Вып. 1. - Тифлис, 1868.

12. Хайбуллаев С.М. Аварская народная лирика. - Махачкала, 1973.

13. Чиркеевский А. Песни и сказки, собранные и переведенные с аварского. Темир-Хан-Шура, 1987.

Поступила в редакичию 24 мая 2019 г.

UDC 398

DOI: $10.21779 / 2542-0313-2019-34-2-27-32$

\section{Satire and humor in Avar folk poetry}

\section{R.M. Magomedova}

Dagestan State University; Russia, 367001, Makhachkala, M. Gadzhiev st., 43a; diyarbilova@mail.ru

The article deals with the problem of using satire and humor in Avar folk songwriting. The ways of creating satire and humor in various genres of Avar folklore are traced; peculiar attention is drawn to some specific features in the use of curse forms in Avar love lyrics and to the corresponding national-cultural components. It is noted that the issues under consideration are of interest not only for folklore, but also for ethnolinguistics and linguoculturology, since it is the folklore texts that differ in their national identity and special national-cultural symbolism. In separate fragments of the article linguistic peculiarities are noted, such as, for example, expressive-estimated use of singular forms of nouns in the meaning of plurality. Special linguistic and cultural significance of the Avar folk songwriting is explained by the fact that it reflects the peculiarities of the national mentality, various gender signs associated with linguistic male and female symbols, which have become cultural markers of the Avar language, which have received a peculiar interpretation in historical terms. The article also draws attention to the prospects for the study of folk song lyrics in various aspects.

Keywords: Avar folklore, songwriting, satire and humor, national and cultural components, language means.

Received 24 May, 2019 